\title{
Stems age, nitrogen fertilizer and salicylic acid application in cutting induction of noble dendrobium orchid of the Yamamoto series cultivars ${ }^{(1)}$
}

\author{
JEFERSON JOÃO SOCCOL ${ }^{(2)}$, GIORGINI AUGUSTO VENTURIERI(3)* ${ }^{(3 N I O ~ L U I Z ~ P E D R O T T I(3) ~}$
}

\begin{abstract}
Propagation of noble dendrobium orchid (Dendrobium nobile Lindl.) by cutting was studied in two experiments. In the first experiment we evaluated the effect stem age on propagation success: mature stems - from already bloomed stems; and young stems - yet to bloom; and Nitrogen fertilizer application, from two sources: as Nitrate and Ammonium (respectively as Calcium Nitrate at concentrations of: $5.81 \mathrm{gL}^{-1} ; 11.61 \mathrm{gL}^{-1} ; 17.42 \mathrm{gL}^{-1}$; and Urea at concentrations of $2.00 \mathrm{gL}^{-1} ; 4.00 \mathrm{gL}^{-1}$ and $6.00 \mathrm{gL}^{-1} \mathrm{plus}$ control treatments). We evaluated the following parameters: the number of cuttings stalks that launched shoots and/or roots, vigor, number of roots per plant and root length per plant. Factorial analysis of variance (stems age $\mathrm{x}$ source of Nitrogen; and age of stem x Nitrogen level) was applied using a Generalized Linear Model (GLM) approach. Where significant differences were observed, averages were compared using post-hoc tests (Tukey). Propagation success was higher using cuttings from mature stems (60.2\%), a value 1.6 times higher than obtained with stem cuttings from young stems (38.0\%). Application of Nitrogen, in both forms, did not influence any of the evaluated parameters. In the second experiment we treated cuttings from mature stems with Salicylic acid in 3 concentrations $(0.10 \mathrm{mM} ; 0.50 \mathrm{mM} ; 1.00 \mathrm{mM}$ and plus a control treatment). Evaluated parameters included proportion of cuttings stalks that launched shoots and/or roots, leaf length, root length, and number of roots per stem cutting. Factorial analysis of variance was applied with post-hoc tests. Application of $0.50 \mathrm{mM}$ of Salicylic acid increased the proportion of cuttings stalks that launched shoots and/or roots by $20.5 \%$ relative to the control treatment.
\end{abstract}

Keywords: Dendrobium nobile, propagation, small farmers, floriculture, elicitor molecule

\section{RESUMO}

Idade dos ramos, aplicação de fertilizantes nitrogenados e ácido salicílico, na estaquia da orquídea olho-de-boneca em cultivares da série Yamamoto

A propagação da orquídea olho-de-boneca (Dendrobium nobile Lindl.) por estaquia, foi estudada em dois experimentos: no primeiro foi avaliado o efeito de duas idades de hastes utilizadas para as estacas: maduras - que já haviam florescido; e jovens que não haviam florescido ainda; e aplicação de fertilizantes nitrogenados, oriundos de duas fontes: na forma de nitrato e na de amônia (respectivamente como nitrato de cálcio nas concentrações de $5,81 \mathrm{gL}^{-1} ; 11,61 \mathrm{gL}^{-1} ; 17,42 \mathrm{gL}^{-1}$; e uréia nas concentrações de 2,00 $\mathrm{gL}^{-1} ; 4,00 \mathrm{gL}^{-1}$ e $6,00 \mathrm{gL}^{-1}$ mais tratamentos controle. Os parâmetros avaliados foram: estacas que lançaram rebentos e/ou raízes, vigor, número de raízes e comprimento de raízes/por planta. A análise de variância fatorial foi aplicada (idade dos ramos x fonte de nitrogênio; e idade dos ramos x nível de nitrogênio) usando o Modelo Linear Generalizado (MLG). Quando diferenças significativas foram observadas, as medias foram comparadas pelo teste de Tukey. O melhor resultado foi obtido usando estacas oriundas de ramos maduros $(60,2 \%)$, valor 1,6 vezes maior que o obtido de estacas oriundas de ramos jovens $(38,0 \%)$. A aplicação de nitrogênio, em ambas as formas, não influenciou qualquer dos parâmetros avaliados. No segundo experimento foram usadas estacas derivadas de ramos maduros tratadas com ácido salicílico em três concentrações $(0,10 \mathrm{mM} ; 0,50 \mathrm{mM} ; 1,00 \mathrm{mM}$ e mais o tratamento controle). Os parâmetros avaliados foram: proporção de estacas que lançaram ramos e/ou raízes, comprimento das folhas por estaca, comprimento das raízes e número de raízes por estaca. Análise de variância fatorial foi aplicada com posterior teste de Tukey. A aplicação de ácido salicílico a $0,50 \mathrm{mM}$ aumentou a proporção de estacas que lançaram ramos e/ou raízes sendo 20,5\% superior ao tratamento controle.

Palavras-chave: Dendrobium nobile, propagação, pequenos agricultores, floricultura, molécula elicitora

\section{INTRODUCTION}

Between 2008 and 2014, growth in flower cultivation in Brazil oscillated between $7 \%$ and $10 \%$ in quantity and $12 \%$ to $15 \%$ in gross sales (SEBRAE, 2015). Assuming an average of $13.5 \%$ growth in revenues, it can be estimated that gross sales in 2016 alone reached US\$ 2.12 billion. The export of orchid scions totaled US\$ 152,000 in 2010 and in the following year US\$ 103,000 , i.e. a decrease of $31.8 \%$. However, over the same period, orchid plantlet imports increased $60.4 \%$, with gross financial product generated rising from US\$ 4.2 to US\$ 6.7 million (SECEX, 2012). Considering that the "plantlet" is the basic input associated with final orchid production, the expansion of such cultivation is occurring predominantly through use of imported plantlets.

\footnotetext{
DOI: http://dx.doi.org/10.14295/oh.v23i2.884

(1) Received in 16/03/2016 and accepted in 28/03/2017

(2) Enterprise of Santa Catarina State for Agricultural Research and Rural Extension (EPAGRI), Xaxim-SC, Br

(3) Federal University of Santa Catarina (UFSC). Agrarian Sciences Center, Plant Science Department, Florianópolis - SC, Brazil. *Corresponding author: giorgini.venturieri@ufsc.br

Licensed by CC BY 4.0
} 
Flower cultivation is a profitable and attractive agricultural sector that involves significant manpower, about 3.8 persons/ha are directly involved in production (REETZ et al., 2007), and high income may be generated in relatively small planted areas. Therefore, flower cultivation is a business that is self-sustainable, able to generate a high number of jobs for local economies, and is accessible to micro-farm holders that use family members as the principle work force. Noble dendrobium orchid (Dendrobium nobile Lindl.) is a fast-growing orchid that grows well in the majority of substrates indicated for orchid propagation. It grows in both low lying and altitudinous regions (up of $2000 \mathrm{~m}$ ). The plant withstands temperatures as low as $1{ }^{\circ} \mathrm{C}$ (BAKER and BAKER, 1996) but requires temperatures of above $22^{\circ} \mathrm{C}$ for good vegetative growth; low temperatures induce flowering that occurs from late winter to early summer (BAKER and BAKER, 1996). Indeed, noble dendrobium is one of the easiest orchids to grow (CAMPOS, 1998; SILVA, 1986). It is one of the three species used in the formulation of "ShiHu" (with D. tosaense and D. moniliforme) (LO et al., 2004; $\mathrm{YE}$ and ZHAO, 2002), which is an antipyretic and tonic drink that is also described as an aphrodisiac in traditional Chinese medicine (HANELT, 2001). It also has antitumor and antimicrobial properties and inhibition of in-vitro lipid peroxidation (DEVI et al., 2009), and anti-retroviral (HIV) properties (SÁNCHEZ-DUFFHUES et al., 2008). If its potential for the pharmaceutical industry is confirmed, there will be a rapid increase in demand for plantlets. Propagation of noble dendrobium orchid, for hobbyists and for small producers, is usually made by clump division, cuttings, or use of the shoots that appear in the axillary buds of leaves, called "Keikes". For commercial purposes propagation by mericlones is preferred. Propagation by seeds has only been adopted for purposes of genetic improvement because it takes twice as long to blossom compared to mericlones, clump division or cuttings.

Cloning of noble dendrobium, by cuttings, has the advantage to be made without laboratorial support as used to produce mericlones; however, its potential to produce plantlets by propagule is higher than clump division, cuttings or "Keikes". Nevertheless, many stem cuttings do not emit leaves or roots and eventually rot. The highest proportion of cuttings stalks that launched shoots and/ or roots obtained with stem cuttings layered on gravel sprinkled with Urea, a nitrogen fertilizer, at $2 \mathrm{gL}^{-1}$, was 40.7\% (VENTURIERI and PICKSCIUS, 2013). Salicylic acid is considered a growth regulator with many positive effects on plants as: flowering stimulant, disease resistance and Ethylene synthesis inhibition (RASKIN, 1992; HAYAT et al., 2010). In the present study, we aimed to improve the propagation of noble dendrobium by cuttings by evaluating the effect of stems age used for cuttings, and potential interactions with nitrogen fertilizer and Salicylic acid application on cutting survival rates and vigor.

\section{MATERIAL AND METHODS}

Cuttings production was evaluated in $D$. nobile using a bulk of 5 genotypes, equally assigned, from Yamamoto series cultivars (Yamamoto Dendrobiums, n.d.), and separated by age of stem (see below) in two different experiments. The two experiments were established in a greenhouse covered with transparent plastic film, superimposed by black plastic screen (Fitela ${ }^{\mathrm{mr}}$ - Engepol, Barueri/SP - Brazil) that is able to block $60 \%$ of incidental light, in Florianópolis, Santa Catarina state, Brazil (27034'55"S; 48 30'19"W). All plants were irrigated for ten minutes, 2-3 times a week throughout the duration of the study.

Experiment 1: Effect of stems age and nitrogen fertilizer application.

For this experiment we used stem cuttings, with 4 buds (approximately $20 \mathrm{~cm}$ in length), from the bulk of the aforementioned cultivars, from stems of two ages: a) mature-stems that had already bloomed in the year since they were collected; and b) young-stems that had not bloomed since collection. Mature and young stems are easily identified as dendrobium's growth occurs in yearly pulses. All stems cuttings were immersed in $1.60 \mathrm{gL}$ ${ }^{1}$ fungicide solution of Mancozeb (Manzate 800 - from DuPont $^{\mathrm{TM}}$, USA), and placed standing on a gravel substrate (previously tested in Venturieri and Pickscius, 2013) in 44.2 x 28.0 x $7.5 \mathrm{~cm}$ plastic trays. For drainage, tray bases were perforated. Applied treatments were: aspersion of Calcium Nitrate (YaraLiva ${ }^{\mathrm{TM}}$ Calcinit $^{\mathrm{TM}}$ - from Yara - Norway, containing $15.5 \%$ of Nitrogen $(\mathrm{N}), 14.4 \% \mathrm{~N}-\mathrm{Nitric}$ and $1.1 \% \mathrm{~N}$-Amoniacal forms, and $19.0 \%$ of hydrosoluble Calcium (Ca)) at concentrations of $5.81 \mathrm{~g} \mathrm{~L}^{-1}, 11.61 \mathrm{~g} \mathrm{~L}^{-1}$ and $17.42 \mathrm{~g} \mathrm{~L}^{-1}$; and Urea (from Buschle and Lepper S.A., Brazil, containing $45.0 \%$ Nitrogen) at concentrations of: $2.00 \mathrm{~g} \mathrm{~L}^{-1}, 4.00 \mathrm{~g} \mathrm{~L}^{-1}$ and $6.00 \mathrm{~g} \mathrm{~L}^{-1}$. The control treatment received only water at the same liquid volume used in other treatments. Aspersions were made up to dripping point. Environmental conditions were: average temperature of 16 ${ }^{\circ} \mathrm{C}\left(\min .=18^{\circ} \mathrm{C}\right.$; $\left.\max .=24{ }^{\circ} \mathrm{C}\right)$, average Relative Humidity of $83 \%(\min .=82 \%$, max. $=84 \%)$. Treatments were applied fortnightly. Concentrations of Calcium Nitrate (mainly $\mathrm{N}$ at nitric form) and Urea ( $\mathrm{N}$ at ammoniac form) were adjusted to make pairs of treatments with the same level of theoretical Nitrogen. Treatments were applied for 3 months. The adopted experimental design was fully randomized, with 4 stem cuttings per plot and 3 plots per treatment. Evaluated parameters included number of cuttings stalks that launched shoots and/or roots, vigor (for this, grades were subjectively accounted for by a consensus of 2 observers as in Venturieri and Pickscius (2013), assigning scores from 0 to 10 , as follows: 0 attributed to rotten stem cuttings and/or without bud leaf or root emission, 5 to stems cuttings with leaf buds of $5 \mathrm{~cm}$ in height, and at least 2 roots, and 10 for stems cuttings with emitted leaf buds of more than $10 \mathrm{~cm}$ with more than 6 roots - intermediate grades could be attributed), number of roots/plant and root length/per plant. To analyze treatment differences and interactions between factors, we used a fully-factorial analysis of variance (stems age $\mathrm{x}$ source of Nitrogen, and age of stem x Nitrogen level) using the Generalized Linear Model (GLM). Where significant differences were observed, averages were compared by the Tukey test for $\alpha=0.05$. Associations between the Nitrogen content by treatment, based in theoretical calculation, and all evaluated 
parameters were estimated by Pearson's correlation index. Due to the high variability of parameters values, we used averages values for each treatment (DYTHAM, 2010).

\section{Experiment 2: Effect of Salicylic acid.}

To test effects of Salicyclic acid we used stem cuttings with 1 bud (approximately $5 \mathrm{~cm}$ in length), from mature stems, from the same genetic material of the previous experiment. Environmental conditions; substrate; period and system of application of the treatments were all equivalent to those described in the previous experiment. The adopted experimental design was fully-randomized with 5 replications (plots) of each treatment with each plot containing 6 stem cuttings. The compared Salicylic acid concentrations were: $0.10 \mathrm{mM} ; 0.50 \mathrm{mM} ; 1.00 \mathrm{mM}$ and a control, that received water only, at the same volume used for the other treatments. The evaluated parameters included proportion of cutting stalks that launched shoots and/or roots, stem cutting leaf length (measured from the root insertion up to the top of the plant), and the length and number of roots. Obtained values were subject to analysis of variance (DYTHAM, 2010).

For both experiments the analyses were made with the aid of the Statistica package 6.0 (Statsolf, Satsoft, Tulsa, United States).

\section{RESULTS AND DISCUSSION}

\section{Experiment 1: Effect of stems age and nitrogen} fertilizer application.

We found significant differences in the proportion of cutting stalks that launched shoots and/or roots as a function stem age $(p \cong 0.0)$, but not Nitrogen source $(p=0.34)$, or the two-way interaction between predictors $(p=0.05)$. For age of stem, the best results were achieved using cuttings from mature stems $(60.2 \%)$, in other words, a value 1.6 times higher than obtained with cuttings from young stems $(38.0 \%)$ (Figure 1).

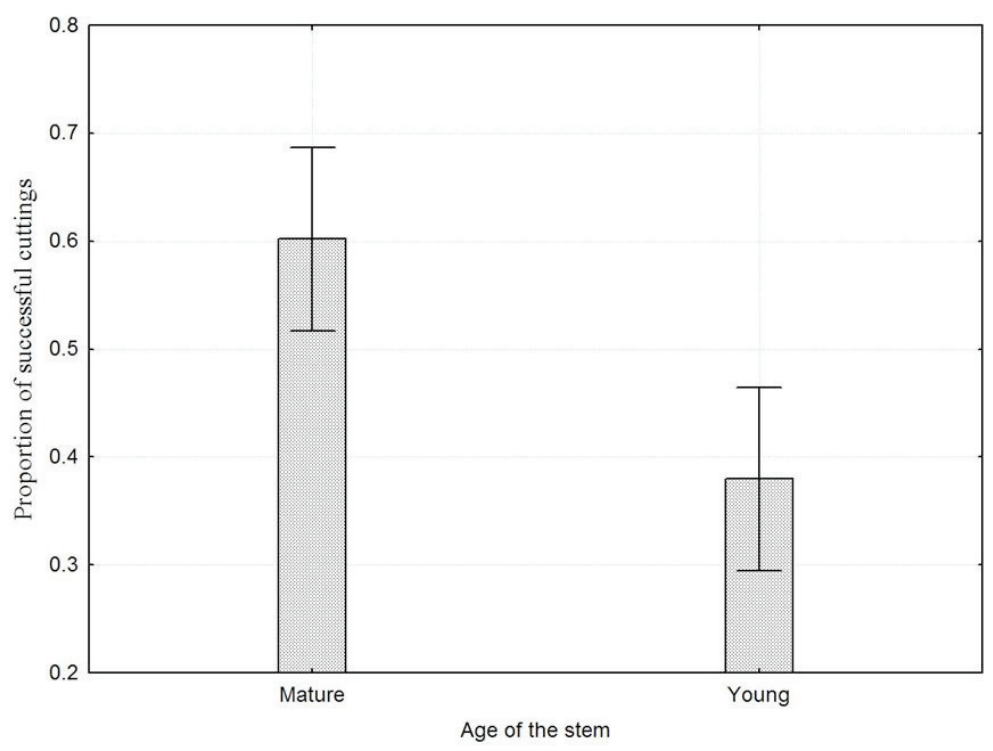

Figure 1. Proportion of successful cuttings, by age of stem that they were taken, when analyzed in function of Nitrogen source. Averages were considered statistically different,

by the Tukey test for $(p \cong 0.0)$. Vertical bars denote $95 \%$ of confidence interval.

The obtained value on mature stem is superior to the $40.7 \%$ obtained by Venturieri and Pickscius (2013) without differentiation of stem cutting ages. According to Raven et al. (1996) auxins are produced at the leaf primordium and in young leaves that inhibit the growth of lateral buds. Older stems are inclined to the soil, assuming, at the end, a prostrate position in the plant, which could also be favor the decrease of the apical dominance promoted by young leaf primordium. As mature stems lack leaves and are usually prostrated, it is presumed that stem cuttings formed from them would have less inhibited lateral buds, explaining the higher proportion of successful cuttings observed on mature stems compared to younger ones.

Also for the parameter proportion of cuttings stalks that launched shoots and/or roots, we found significant difference for the age of the stem $(p \cong 0.0)$ (Figure 2$)$ and no statistical difference for Nitrogen level $(p=0.06)$. No interaction between these factor were observed $(p=0.71)$. 


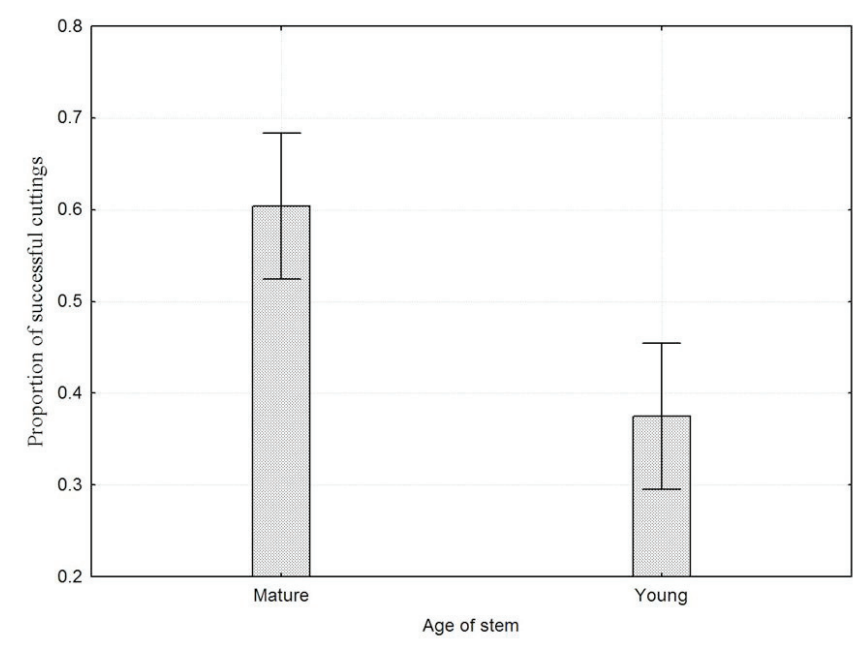

Figure 2. Proportion of successful cuttings, by age of stem that they were taken, in function of Nitrogen level. Averages were considered statistically different, by the Tukey test for $(p \cong 0.0)$.

Vertical bars denote $95 \%$ of confidence interval.

Our findings that nitrogen application neither directly, nor through an interaction with stem age, influenced the proportion of viable cut stems was in agreement with results presented in a similar experiment by Venturieri and Pickscius (2013), where application of Nitrogen in the form of Urea to noble dendrobium stem cuttings, not differentiated by ages, found no effect on the proportion of stem cuttings that launched shoots and/or roots.
Age of the stem $(p=0.01)$ showed significant difference, but not Nitrogen source $(p=0.43)$, or the interaction between age of the stem and Nitrogen source $(p=0.92)$, significantly affected plant vigor (Figure 3 ), reflecting that stem age is also an important factor for this parameter and that Nitrogen is not.

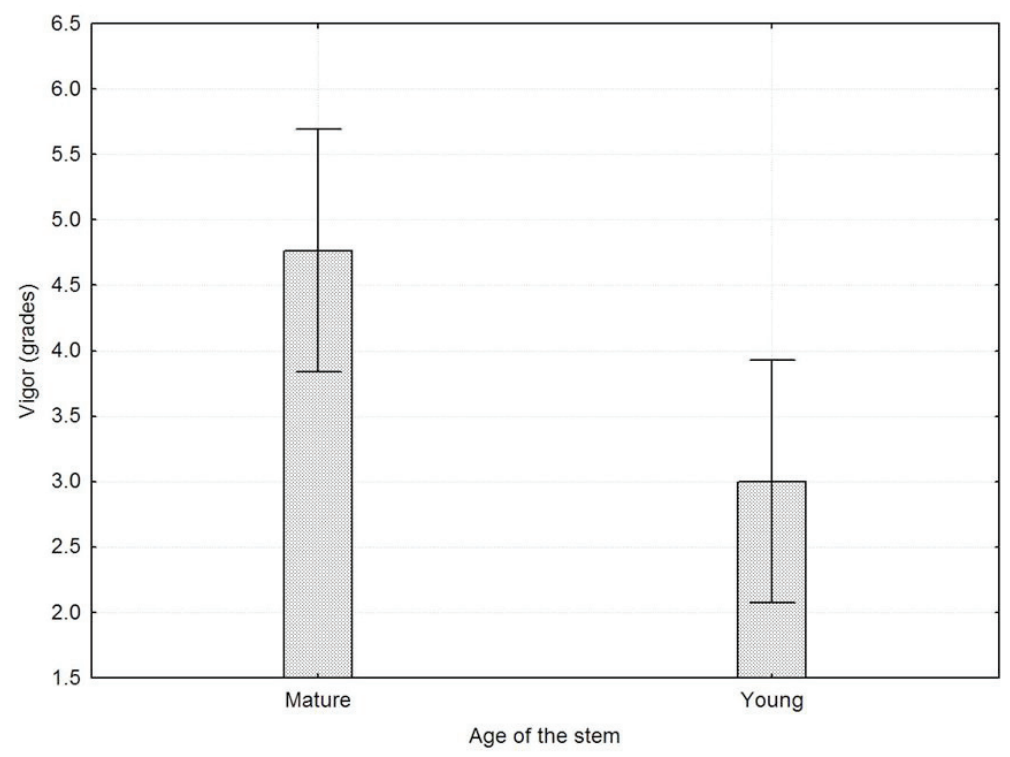

Figure 3. Vigor of cuttings stalks that launched shoots and/or roots, by age of stem that they were taken, in function of Nitrogen source. Averages were considered statistically different, by the Tukey test for $(p=0.01)$. Vertical bars denote $95 \%$ of confidence interval.

For the vigor in function of the age of the stem and the Nitrogen level there was difference for the age of the stem $(p$ $=0.01)$ (Figure 4$)$ and no statistical difference for Nitrogen level $(p=0.90)$ and even interaction between them $(p=$ 0.97 ) also, reflecting the age of stem is also influent for this parameter and Nitrogen application not. 


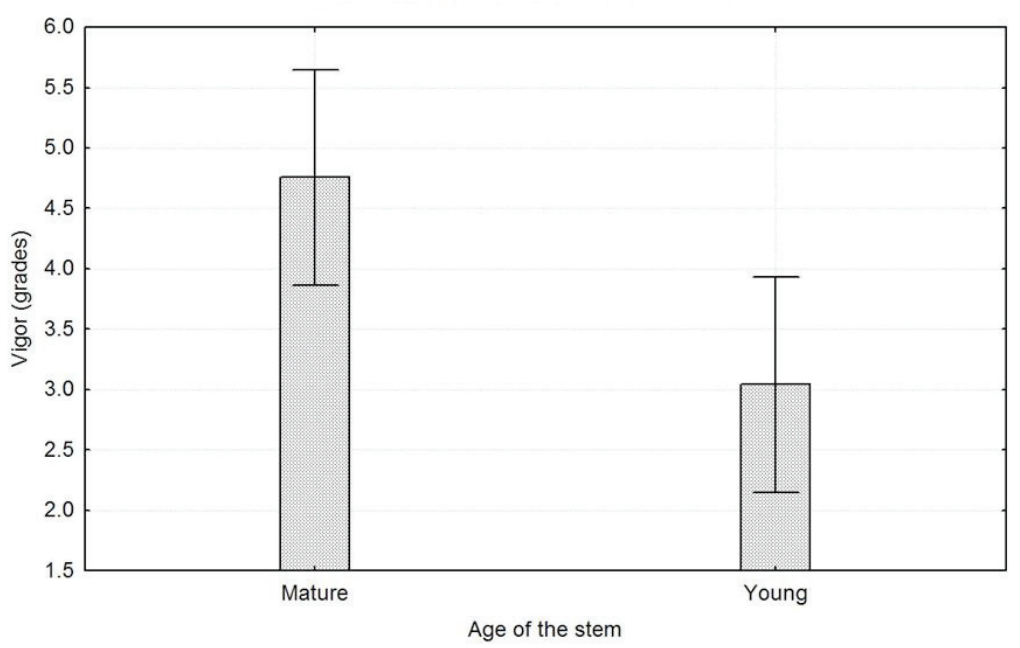

Figure 4. Vigor of cuttings stalks that launched shoots and/or roots, analyzed by age of stem that they were taken, in function of the Nitrogen level. Averages were considered statistically different, by the Tukey test for $(p=0.01)$. Vertical bars denote $95 \%$ of confidence interval.

For the parameter number of roots per plant, no significant differences were observed for age of the stem and Nitrogen source (respectively $r=0.48$ and 0.43 ), or their interaction $(r=0.78)$. For the same parameter no significant difference was also observed for age of the stem and Nitrogen level (respectively $r=0.53$ and 0.45 ) and their interaction $(r=0.46)$ either.

For the parameter root length per plant, no significant differences were observed for age of the stem and source of Nitrogen (respectively $r=0.29$ and 0.09 ), or their interaction $(r=0.98)$. For the same parameter no significant difference were also observed for age of the stem and Nitrogen level $(r=0.27$ and 0.18$)$ and their interaction either $(r=0.61)$.

A significant negative correlation was observed between theoretical Nitrogen levels and number of roots $(r=-0.88)$, and also with root length per plant $(r=0.90)$. Number of roots and root length per plant were positively correlated $(r=0.8)$. So, as far as the level of Nitrogen was increased, fewer roots were emitted in number and in length. A similar effect was observed in vitro cultivation of Phalaenopsis hybrids, where increases in $\mathrm{NH}_{4}^{+}$and $\mathrm{NO}_{3}^{-}$concentration decreased root growth (HINNEN et al., 1989) and, by the observed associations, it can be supposed that, Nitrogen offer for cuttings of mature stalks may depress root emission.

Application of Nitrogen in the form of Urea or even in the form of Nitrate, as observed in the present work, had no influence on all evaluated parameters and so, its use is not recommended for the process of noble dendrobium of the Yamamoto series cultivars cuttings formation.

\section{Experiment 2: Effect of Salicylic acid.}

Among evaluated parameters, application of Salicylic acid had a significant effect on the proportion of cutting stalks that launched shoots and/or roots only $(p \cong 0.0)$. The highest observed value (43.3\%) was in the treatment which received $0.50 \mathrm{mM}$ of Salicylic acid. Despite its statistical equivalence to the treatments that received $0.1 \mathrm{mM}$ or 1.0 $\mathrm{mM}$, it was 1.86 times higher than observed for the control treatment (23.3\%) (Figure 5).

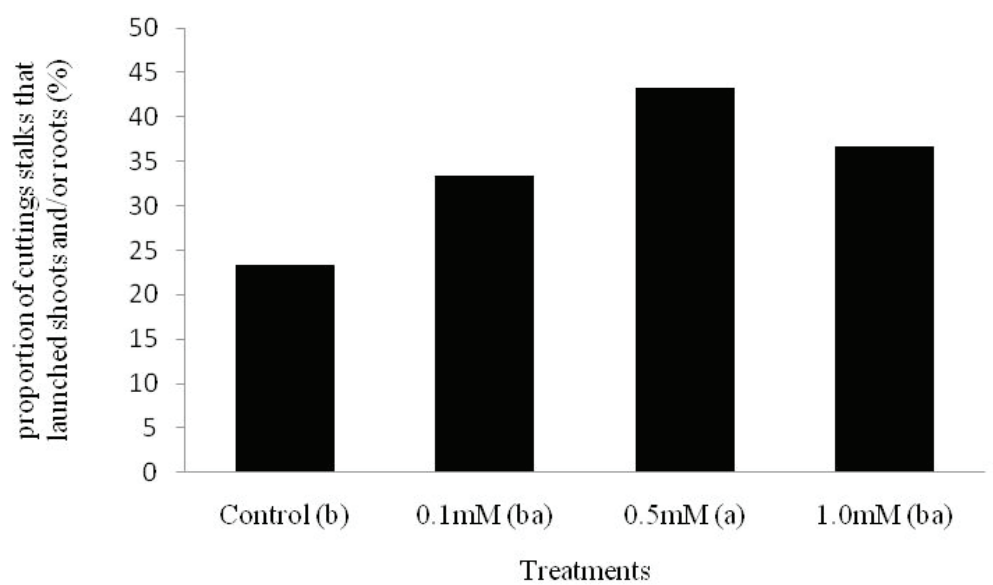

Figure 5. Proportion of cuttings stalks that launched shoots and/or roots in function of the application of Salicylic acid. Averages followed by the same letter do not differ statically by the Tukey test (for $\alpha=0.05$ ). 
Salicylic acid is involved in many physiological processes in plants, among these resistance against pathogens, net photosynthetic rate and stomata closure (RASKIN, 1992; HAYAT et al., 2010), that could have incrementally contributed to proportion of cuttings stalks that launched shoots and/or roots. Salicylic acid decreased the number and formation of Protocorm-like bodies (PLB) on Cymbidium orchids at a concentration of $14 \mathrm{mM}$ (ÇANAKCI and MUNZUROGLU, 2009), and, in the present experiment, the highest tested concentration was $1.0 \mathrm{mM}$ showed a reduction of $7 \%$ in proportion of cuttings stalks that launched shoots and/or roots in relation to obtained with the dosage of $0.5 \mathrm{mM}$ (Figure 1). We therefore predict that the application of Salicylic acid, at high concentrations could induce phytotoxicity, reported here to be applications higher than $0.5 \mathrm{mM}$.

\section{CONCLUSIONS}

- Mature stems achieved the highest proportion of cutting stalks that launched shoots and/or roots, vigor, number of roots per plant and root length per plant.

- Application of Nitrogen, in the ammoniac or nitric forms, did not benefit any of the evaluated parameters.

- Nitrogen offer in cuttings, particularly mature stalks, may depress root emission.

- Application of Salicylic acid at concentration of 0.50 $\mathrm{mM}$ increased the proportion of successful cuttings of $D$. nobile Yamamoto series cultivars.

- The use of mature stems and the application of Salicylic acid can be deployed, at commercial level, without necessity of a tissue culture laboratory to make cuttings of noble dendrobium of the Yamamoto series cultivars.

\section{ACKNOWLEDGMENTS}

To colleagues Antônio Correa Garcia and Jefferson Sandi for the help during the execution of the present experiments. To Mr. José Francisco Nunes Filho for the genetic material supplied. And we also acknowledge Dr. César Assis Butignol, for the critical revision of the manuscript and Dr. Alistair Campbell for linguistic advice.

\section{AUTHORS CONTRIBUTION}

J.J.S.: Creation of the idea, literature review, experimental field works, data collection, redaction of the paper; G.A.V.: broad conception of the project, experimental planning, statistical analysis of data, redaction of the paper; E.L.P.: Logistic facilities and funds, critical review with important suggestions incorporated to the work.

\section{REFERENCES}

BAKER, M.; BAKER, C.O. Orchid Species Culture. Dendrobium. Oregon, USA: Timber Press. Portland, 1996. $852 \mathrm{p}$.

ÇANAKCI, S.; MUNZUROGLU, Ö. Effects of Salicylic acid on growth and chlorophyll destruction of some plant tissues. World Journal of Agricultural Sciences, v.5, p.577-581, 2009.

DEVI, P.U.; SELVI, S.; DEVIPRIYA, D.; MURUGAN, S.; SUJA, S. Antitumor and antimicrobial activities and inhibition of in-vitro lipid peroxidation by Dendrobium nobile. African Journal of Biotechnology, v.8, n.10, p.2289-2293, 2009. DOI: https://doi.org/10.4314/ajb. v8i10.60575.

DYTHAM, C. Choosing and Using Statistics: A Biologist's Guide, (3rd edition). West Sussex, USA: Wiley-Blackwell, 2010, 320p.

HANELT, P. Mansfeld's Encyclopedia of Agricultural and Horticultural Crops. Gatersleben: Springer, Institut Für Pflanzengenetikund Kulturflanzen - IPK, 2001. 3641 p.

HAYAT, Q.; HAYAT, S.; IRFAN, M.; AHMAD, A. Effect of exogenous salicylic acid under changing environment: A review. Environmental and Experimental Botany, v.68, p.14-25. 2010. DOI: http://dx.doi.org/10.1016/j. envexpbot.2009.08.005

HINNEN, M.G.J.; PIERIK, R.L.M.; BRONSEMA, F.B.F. The influence of macronutrients and some other factors on growth of Phalaenopsis hybrid seedlings in vitro. Scientia Horticulturae, v.41, n.1-2, p.105-116, 1989. DOI: https:// doi.org/10.1016/0304-4238(89)90054-X

LO, S-F.; NALAWADE, S.M.; KUO, C-L.; CHEN, C-L.; TSAY, H-S. Asymbiotic Germination of Immature Seeds, Plantlet Development and Ex Vitro Establishment of Plants of Dendrobium tosaense Makino - A Medicinally Important Orchid. In Vitro Cellular \& Developmental Biology - Plant, v.40, n.5, p.528-535, 2004. DOI: 10.1079/ IVP2004571

RASKIN, I. Role of salicylic acid in plants. Annual Review of Plant Physiology and Plant Molecular Biology, v.43, n.16, p.439-463, 1992. 
RAVEN, P.H.; EVERT, R.F.; EICHHORN, S.E. Biologia Vegetal. Rio de Janeiro: Kogan S.A., Guanabara, Brasil, 1996. 728 p.

REETZ, E.R.; CLEITON, S.; RIGON, L.; CORREA, S.; LINDEMANN, C. E.; BELING, R.R. Anuário Brasileiro das Flores. Sta. Cruz do Sul, Brasil: Ed. Gazeta, 2007. $112 \mathrm{p}$.

SANCHEZ-DUFFHUES, G., CALZADO, M.A., VINUESA, A.G. DE, CABALLERO, F.J., ECHCHAHAD, A., APPEMDINO, G., KROHN, K., FIEBICH, B.L., MUNOZ, E. Denbinobin, a naturally occurring 1,4-phenanthrenequinone, inhibits HIV-1 replication through an NF- $\kappa$ B-dependent pathway. Biochemical Pharmacology, v.76, n.10, p. 1240-1250, 2008. DOI: https://doi.org/10.1016/j.bcp.2008.09.006

SEBRAE. Flores e plantas ornamentais do Brasil. (Série Estudos Mercadológicos), volume 1. Brasília: SEBRAE, 2015. 42 p.
Secretaria de Comércio Exterior. Sistema de Análise das Informações de Comércio Exterior (Alice Web), 2012 (2012), Available at http://aliceweb2.mdic.gov.br/, Accessed at: 20/05/2012.

VENTURIERI, G.A.; PICKSCIUS, F.J. Propagation of nobile dendrobium (Dendrobium nobile Lindl.) by cutting. Acta Scientiarum Agronomy, v.35, n.4, p.501-504, 2013. DOI: http://dx.doi.org/10.4025/actasciagron.v35i4.15198

SILVA, W. 1986. O cultivo de orquídeas no Brasil, 6ed., São Paulo: 1986. 96p.

YAMAMOTO DENDROBIUMS n.d. General Carrying: Fertilizing. Available at: < http://aliceweb2.mdic.gov.br/> Accessed on: 24/02/2017.

YE, Q.; ZHAO, W. New Alloaromadendrane, Cadinene and Cyclocopacamphane Type Sesquiterpene Derivatives and Bibenzyls from Dendrobium nobile. Planta Medica, v.68, n. p.723-729, 2002. DOI: https://www.thieme-connect.de/ DOI/DOI?10.1055/s-2002-33786 